\title{
THE INCIDENCE, PERCEIVED MERIT AND ANTECEDENTS \\ OF CUSTOMER ACCOUNTING: AN EXPLORATORY NOTE
}

\section{CHRIS GUILDING}

and

LISA McMANUS

School of Accounting and Finance, Faculty of Commerce and Management,

Griffith University.

Acknowledgements: This paper has benefited from discussions with Ross Guest (School of Accounting \& Finance, Griffith University). We also acknowledge the helpful comments provided by two anonymous referees. 


\title{
THE INCIDENCE, PERCEIVED MERIT AND ANTECEDENTS OF CUSTOMER ACCOUNTING: AN EXPLORATORY NOTE
}

\begin{abstract}
The results of a survey appraising the frequency and perceived merit of customer accounting (CA) practices are reported. Given the limited attention afforded the subject in the normative and empirical literatures, CA usage appears to be greater than what might have been reasonably anticipated. Evidence of a positive association between market orientation and CA, as well as a weak positive association between competition intensity and CA is provided.
\end{abstract}

Key words: Customer accounting, competition intensity, market orientation, strategic management accounting. 


\section{THE INCIDENCE, PERCEIVED MERIT AND ANTECEDENTS OF CUSTOMER ACCOUNTING: AN EXPLORATORY NOTE}

There appears to be a growing tendency for companies to seek competitive advantage by applying customer-focused strategies. ${ }^{1}$ Customer-focused strategies have received considerable recent attention in the burgeoning marketing literature concerned with 'relationship marketing' (Cravens, 1995; Gronroos, 1994). Contemporaneously, there has been a growth in the number of accounting commentaries (although there are still relatively few), that propose adopting customers and customer segments as units of accounting analysis (e.g., Bellis-Jones, 1989; Foster et al, 1996). A literature search reveals, however, no prior empirical work concerned with appraising the incidence or antecedents of customer accounting (CA). Foster and Young (1997) highlight this shortcoming of management accounting research by contrasting the high importance attached by practitioners to customer management issues with the relative dearth of empirical research concerned with customer accounting. ${ }^{2}$ The study reported herein was conducted in light of this apparent gap in the literature. The study's objectives are:

1. to appraise the incidence of CA;

2. to assess practitioner's perceptions of CA's merit as a managerial tool; and

3. to develop and test hypotheses concerned with contingent factors that might affect the use and perceived merit of CA.

The remainder of the paper is structured as follows. In the context of a review of what practices comprise CA, the next section provides a synthesis of the most pertinent literature. Hypotheses are then developed concerning factors that might impact upon the usage rates and perceived merit of CA. Subsequent sections address, in turn, the empirical research methods employed, the empirical results and a conclusion that discusses the study's most significant findings, its limitations as well as possible avenues for future research.

\section{CUSTOMER ACCOUNTING PRACTICES}

As might be anticipated in a fledgling literature, no prior attempt to delineate the practices comprising CA has been found. The absence of a taxonomy poses significant problems as it necessitates the exercise of some subjective judgement in the development of an underlying framework of CA practices. This issue should be placed in context, however, as it is a demarcation problem confronted whenever an attempt is made to itemise related constructs. ${ }^{3}$ In an attempt to delimit this problem, significant emphasis has been attached to the way that CA practices have been described in the literature. The following five dimensions of CA have been identified:

(i) customer profitability analysis,

\footnotetext{
${ }^{1}$ Kaplan and Norton (1992) note that this customer-focus is evident from the number of companies including customer-specific proclamations in their corporate mission statements.

${ }^{2}$ From their survey of American and Australian managers, Foster and Young (1997) found "customer profitability/satisfaction" to be "the single most important current management priority" (p.69). Foster and Young considered this finding in the context of Shields' (1997) management accounting literature review that failed to find a single study concerned with "customer profitability/satisfaction" between 1990 and 1996.

${ }^{3}$ For example, despite the considerable cumulative effort directed towards describing "management accounting”, a review of widely-used texts reveals limited consensus on what constitutes an appropriate demarcation of the subject's constituent practices.
} 
(ii) customer segment profitability analysis,

(iii) lifetime customer profitability analysis,

(iv) valuation of customers or customer groups as assets, and;

(v) customer accounting (i.e., the holistic notion).

Before elaborating on these dimensions of CA, it should be noted that elements of CA appear to be embedded in several recently promoted management tools and philosophies. For example, one of the four dimensions of performance promoted by Kaplan and Norton (1992; 1996) in their "Balanced Scorecard" writings concerns the customer and the need to monitor rates of customer acquisition, retention and satisfaction. Themes in the "Total Quality Management" literature highlight the importance of monitoring customer complaints, lost customers as well as increased sales resulting from improved quality performance (Feigenbaum, 1983; Zink, 1995). Further, the relationship marketing school of thought carries implications for securing greater customer accountability (Christopher et al., 1991; Gronroos, 1994). By identifying and addressing the five dimensions of CA referred to above, the current study can be seen to elevate CA above the standing of practices subordinated to other overarching management initiatives.

Each of the five CA practices are now described in turn. In the course of describing the CA practices, the way that the constructs were operationalised in the empirical phase of the study is also outlined.

(i) Customer profitability analysis (CPA) appears to be the most widely referred to CA practice in the literature. Commentaries include Bellis-Jones (1989), Cooper and Kaplan (1991), Dudick (1987), Juras and Dierks (1993), O’Guin and Rebishke (1993), Shapiro et al. (1987), Smith and Dikolli (1995) and Ward (1992). Cooper and Kaplan's (1991) Kanthal "A" case typifies many of these studies as it demonstrates how the activity based costing framework can be applied when customers are the unit of analysis. Kanthal, a heating element manufacturer, had traditionally allocated customer-related selling costs on the basis of sales revenue. By replacing this approach with a system that allocated ordering costs based on the number of orders placed, and non-standard item servicing costs based on the number of non-standard items purchased, the company discovered that only $40 \%$ of its customers were profitable. CPA was operationalised in this study's empirical phase in the following way:

This involves calculating profit earned from a specific customer. The profit calculation is based on costs and sales that can be traced to a particular customer. This technique is sometimes referred to as "Customer Account Profitability”.

(ii) Customer segment profitability analysis is the same as CPA except for the fact that customer segments rather than individual customers comprise the unit of analysis. This form of CPA has been discussed by Ward (1992), and is considered in the context of a documented case by Cooper and Kaplan (1991) and a hypothetical case by Quain (1992). ${ }^{4}$ Several commentaries on customer segment profitability analysis note that it may have particular potential when applied in the banking industry. It would appear that the relatively small margins that banks earn on the majority of accounts preclude the feasibility of operationalising a customer accounting system at the individual customer

\footnotetext{
${ }^{4}$ Cooper and Kaplan’s (1991) “Winchell Lighting” case concerns a light fixture manufacturer, while Quain's study concerns a hypothetical hotel chain.
} 
level (Hartfeil, 1996; Hudson, 1994). Customer segment profitability analysis was operationalised in the study's empirical phase as:

This is the practice of performing a customer profitability analysis (as defined above), on a market segment or customer group basis.

(iii) Foster and Gupta (1994) note that a minimally explored area of CPA is the lifetime analysis of customers. This practice involves extending the basic CPA to incorporate the future profitability projected to accrue over the lifetime of customer trading relationships. Foster and Gupta suggest this technique might be usefully applied in the life insurance industry. Cooper and Kaplan's (1991) Manufacturers Hanover case is valuable as it represents the only documented case outlining the application of this CA model. This case concerns a bank and describes a loan pricing model involving the estimation of the profitability of individual loan transactions by projecting revenues (eg., fees and interest income) as well as expenses over the lifetime of proposed customer loans. Lifetime customer profitability analysis was operationalised in the study's empirical phase as:

This involves extending the time horizon for customer profitability analysis to include future years. The practice focuses on all anticipated future revenue streams and costs involved in servicing a particular customer.

(iv) Foster et al's (1996) work represents the first study in the accounting literature to offer any elaboration of the notion of valuing customers as assets. Outside this work, the closest that the accounting literature comes to broaching the subject has been found in Foster and Gupta (1994) and Ward (1992) where the word "asset" is used in connection with customers. ${ }^{5}$ The accounting literature's failing in this regard is particularly striking when considered in the context of the marketing literature where it appears viewing customers as assets is a fundamental axiom. For example, Cravens et al. state 'customer value ..... is a valuable asset' (1997: 497). Similarly, Levitt states 'a company's most precious asset is its relationship with its customers .... like any other assets, these relationships can appreciate or depreciate' (1983: 91-92). Recognition of this shortcoming of accounting is not restricted to academics, however. Albrecht quotes Jan Carlson, the former CEO of the airline $S A S$, in the following manner:

"Look at our balance sheet. On the asset side, you can still see so-and-so many aircraft worth so-and-so many billions. But its wrong; we are fooling ourselves. What we should put on the asset side is, last year SAS carried so-and-so many happy passengers. Because that is the only asset we've got - people who are happy with our service and are willing to come back and pay for it once again” (1988: p. 23).

Viewing customers as assets is a notion that closely parallels 'relationship marketing' theorising which has commanded significant recent interest amongst marketing commentators. It is widely-held amongst relationship marketing proponents that the value of the customer relationship should be assessed and recognised for internal management purposes (e.g., Berry, 1977; Christopher et al., 1991; Dwyer et al., 1987).

A literature search has revealed no systematic outline of how customer value can be determined, although a number of marketing commentaries discuss customer value in terms of future cashflows and profit streams (Reichheld, 1993; Sonnenberg, 1994;

\footnotetext{
${ }^{5}$ Tangentially related is Guilding and Pike's 1990 theoretical consideration of intangible marketing assets. This commentary affords no specific attention to customers as assets, however. Guilding et al (2001) elaborate on customer asset accounting in a review of customer accounting's potential in the hotel industry.
} 
Turnbull and Wilson, 1989; Wayland and Cole, 1994). For the purposes of this study's empirical phase, the practice was referred to as "Valuation of Customers or Customer Groups as Assets", and was operationalised in the following manner:

Valuation of customers or customer groups as assets refers to the calculation of the value of customers to the company. For example, this could be undertaken by computing the present value of all future profit streams attributable to a particular customer or group of customers.

(v) In light of this study's exploratory nature and the very limited (and limiting) nature of the prior literature, one further dimension of CA has been appraised. This is the holistic dimension, i.e., the over-arching construct that defines the subject of the study's inquiry. This construct has been labelled "customer accounting" and was operationalised in the study's empirical phase in the following manner:

Customer accounting includes all accounting practices directed towards appraising profit, sales, or present value of earnings relating to a customer or group of customers.

\section{A CONTINGENCY THEORY OF CUSTOMER ACCOUNTING}

In this section, hypotheses concerning two factors that might exhibit a contingency relationship with CA are developed. These contingent factors are: (i) intensity of competition; and (ii) market orientation. For the reasons outlined below, in advance of collecting empirical data, these two factors predominated when conceiving of factors potentially related to the use and perceived merit of CA. Several other factors such as competitive strategy and environmental uncertainty were also considered for inclusion in the study, however a desire to limit the survey questionnaire to two pages limited the scope of the contingency examination undertaken.

\section{(i) Intensity of Competition.}

Bellis-Jones (1989) and Foster and Gupta (1994) suggest that CA systems may be particularly appropriate in firms operating in highly competitive markets. Kohli and Jaworski (1990) assert that greater competition creates a heightened need to focus on the customer and to analyse performance in a manner consistent with providing insights concerning customer desires and how customer value can be created. Further, Lynch and Cross's (1991) claim that organisations facing higher competition are likely to use multiple performance measures is pertinent, as balanced scorecard commentaries highlight the potential for CA's inclusion in a broader base of performance measures (Kaplan and Norton, 1992; 1996). This view that CA is positively associated with competition appears consistent with Khandwalla's (1972) finding of a positive relationship between management accounting system sophistication and competition intensity.

In the case of low competition, which is apparent in government regulated markets and monopolies, there is limited call for CA as customers are constrained in their ability to change suppliers and fixed prices signify limited variability in customer profit levels. Greater competition signifies a greater impetus for companies to find ways to differentiate their products and services from those provided by competitors. This onus frequently results in a greater number of product and service lines offered and also increased customer segmentation (Kaplan and Norton, 1996; Rolfe, 1992). In addition, it results in differentiation sought through increased customisation of products and services in order to 
meet specific customer desires. Greater product and service customisation as well as customer segmentation signifies a greater need for CA due to greater cross-customer variations in profitability and a heightened need for cross-customer resource allocation decision making.

Greater competition intensity has also resulted in many companies developing customer retention initiatives such as customer loyalty programmes (Reicheld and Sasser, 1990; Reicheld, 1993). The advent of such initiatives signify a heightened need for customer profitability information in order to highlight which customers should be targeted. Greater competition can also be expected to result in more imaginative marketing practices such as loss leader and package deal pricing (Evans and Berman, 1994). Determining which product or service to use in such pricing initiatives necessitates an understanding of customer purchasing behaviour and, again, a consideration of which customers are to be targeted. As lower margins can be expected in relatively intense market conditions, the incidence of loss and low profit yielding customer relationships can be expected to increase with higher levels of competition intensity.

The reasoning offered thus far suggests a positive relationship between competition intensity and CA usage. This view needs to be qualified, however, in order to recognise those situations where the degree of competition approaches perfect competition. Perfect competition signifies a substantially altered state as all sales to customers would be equally profitable, thereby negating much of the need for CA. Also, in perfect competition there would be an erosion of repeat purchasing by loyal customers, as firms become price takers in their offering of identical products and services. This erosion of customer loyalty undermines the merit of CA, and especially customer valuation due to its association with the notion of relationship marketing.

In light of this reasoning, one may anticipate an inverted-U relationship between competition intensity and CA, i.e., CA usage and CA's perceived merit will be relatively low in the presence of extremely low and high levels of competition, and relatively high in the presence of medium levels of competition. Hypotheses 1a and 1b are postulated in a manner consistent with this rationale.

Hypothesis 1a: CA usage rates are higher in companies experiencing medium levels of competition intensity.

Hypothesis 1b: Perceived managerial benefit of CA is greater in companies experiencing medium levels of competition intensity.

Market Orientation.

"A business that increases its market orientation will improve its market performance. This proclamation has been issued continuously by both marketing academicians and marketing managers for more than 30 years (see, e.g., Kotler, 1984; Kotler and Andreasen, 1987; Levitt, 1960, Webster, 1988). Judged by the attention paid to it by practitioners and academicians in speeches, textbooks, and scholarly papers, marketing orientation is the very heart of marketing management and strategy .....” (Narver and Slater, 1990: 20).

This espoused significance for "market orientation" motivates its examination in an accounting study that has as its central focus a marketing construct, i.e., customers. Firms 
with a high market orientation have, by definition, a relatively strong external focus (Kotler, 1984). Conventional management accounting systems have been criticised for an excessive internal orientation (Piercy, 1986; Wilson, 1986). This tendency for an internal orientation can be expected to be tempered in those firms exhibiting a high market orientation. As a company's customer base is a construct residing outside the organisation, it is expected that customer accounting systems will tend to be more developed in highly market orientated companies. In fact Kohli and Jaworski (1990) see a customer focus as the central element of a market orientation, and Narver and Slater (1990) conclude that a customer orientation is one of three behavioural constructs underlying market orientation (the other two being: competitor orientation and inter-functional coordination).

It is also expected that firms with a strong market orientation will tend to attach a relatively high degree of importance to the acquisition of marketing-orientated knowledge such as customer-related information (Slater and Narver, 1994). Furthermore, firms with a strong marketing focus can be expected to incur relatively large discretionary marketing costs in areas such as customer support. This larger expenditure would appear to warrant higher levels of customer accounting, as customer accounting can inform decisions concerning allocation of the customer support budget. The greater customer focus implicit to a high market orientation is also expected to impact positively on management's perception of the managerial benefits that may derive from CA. Following this rationale it is hypothesised that:

Hypothesis 2a: CA usage rates are higher in companies with a high market orientation. Hypothesis 2b: Perceived managerial benefit of CA is greater in companies with a high market orientation.

\section{METHOD AND VARIABLE MEASUREMENT}

\section{Sampling procedures}

Data were collected via a mailed questionnaire survey. ${ }^{6}$ The initial sample comprised the top 300 Australian listed companies (measured by market capitalisation), obtained from the "Shareholder" CD-Rom database. Of this initial sample, no Australian address could be found for 15 companies, 9 company addresses were found to be incorrect, 22 companies advised in writing that the issues raised in the survey were not applicable to them, ${ }^{7}$ and 3 companies advised that participation in the study would contravene company policy. The final adjusted sample size is 251 companies.

As part of a strategy designed to increase the number of companies represented in the data analysis, the questionnaire, a covering letter, return self addressed envelope, and a crossreferenced glossary of customer accounting practices was mailed to the chief accountant and marketing manager in each company. A second mail-out to all non-respondents was undertaken two weeks following the initial mailing. 148 usable responses were received from 95 chief accountants and 53 marketing managers representing 124 companies. This equates to a response rate of $49.4 \%$ of the companies sampled. In the 24 cases where two responses were received from the same company, the information provided by the

\footnotetext{
${ }^{6}$ A pilot study involving a review of the questionnaire by eight academics, was conducted in order to minimise the potential for ambiguity in the survey questions.

${ }^{7} 19$ of these were mining companies that indicated that due to a number of reasons (such as "in exploration stage") they did not have any customers and the survey was not applicable.
} 
marketing manager was not included in the data analysed. This approach is consistent with promoting greater homogeneity, as the accountants returned the greater number of questionnaires. $^{8}$

Two investigations for non-response bias were undertaken. Firstly, ten randomly selected non-respondents were contacted by telephone and encouraged to participate in the study. Six of these advised that they had not participated due to time constraints, and four advised that participation contravened company policy. No comments giving rise to a concern for non-response bias were made. The second approach involved applying the Mann-Whitney $U$ statistic in an investigation for differences in responses provided by early and late respondents. The first and last $25 \%$ of questionnaires returned were analysed and no statistically significant differences across the two sub-samples were noted.

\section{Variable Measurement}

CA Usage. Following the question, "To what extent does your company use the following practices?", the five CA practices were listed. Next to each one, a Likert scale ranging from 1 ("not at all"), to 7 ("to a large extent") was provided. In addition, respondents could indicate "N.A." if a particular approach was not applicable to their organisation. ${ }^{9}$ To promote consistent interpretation of the CA practices referred to in the questionnaire, a glossary outlining the earlier-noted operationalisation of each CA construct was included in the mail-out.

Perceived Managerial Merit of CA. The perceived managerial merit of the five CA items was measured using the same seven point Likert scale described above. Respondents were asked "To what extent do you consider the following practices would be a useful aid to management in your company?”.

Intensity of Competition. Intensity of competition was measured by supplementing the three items employed by Khandwalla (1972) with two additional items. Following Khandwalla, respondents were asked to rate the intensity of competition for selling and distribution, quality and variety of products, and price. In addition, they were asked to rate the intensity of competition for market share and competition relating to customer service. All five items were rated on a seven point Likert scale, ranging from " 1 " (negligible intensity) to “7” (extremely intense).

A principal components analysis of these five items was conducted and yielded one factor with an eigenvalue greater than one (3.66). This factor had an explained variance of $73.2 \%$ and item factor loadings of $0.880,0.857,0.854,0.846$ and 0.840 , respectively. The Cronbach alpha for these five items was 0.91 . The analysis indicated that the construct was unidimensional and reliable. The factor scored variable was used in the statistical analyses reported on below (Hair et al., 1995; Tabachnick and Fidell, 1996).

\footnotetext{
${ }^{8}$ Before the duplications were eliminated from the analysis, an investigation was made for any inconsistent information provided by representatives of the same company. No significant differences were noted.

${ }^{9}$ As the study's third objective concerns appraising factors affecting CA usage rates and also CA's perceived merit, following preliminary descriptive analyses, respondents reporting "N/A" (not applicable) were coded as " 1 " for the five usage rates (i.e., not used at all) and also " 1 " for their perceived merit, (i.e., perceived as not at all useful). Depending on the variables under analysis, this increased the $n$ by between 12 to 23 cases. It has been found that rerunning the analyses on a data set that excludes the "N/A" responses carries minimal implications for the reported results.
} 
Market Orientation. Market orientation was measured using a slightly modified version of the instrument applied by Cravens and Guilding (1999). Cravens and Guilding's measure draws on Narver and Slater's (1990) pioneering work concerned with validating a measure of market orientation. In the present study, using a seven point Likert scale that ranged from " 1 " (not at all) to "7” (to a large extent), managers were asked to indicate the extent to which they agree with the following four statements:

- my company has a strong understanding of our customers,

- the functions in my company work closely together to create superior value for our customers,

- management in my organisation thinks in terms of serving the needs and wants of well-defined markets chosen for their long-term growth and profit potential for the company, and;

- my company has a strong market orientation.

The first three of these items were used in the Cravens and Guilding (1999) study. The fourth item was designed as a surrogate measure of the holistic market orientation construct. A principal components factor analysis performed on these four items revealed one factor with an eigenvalue greater than one (2.81) and an explained variance of $70.3 \%$. The factor loadings for each item were $0.764,0.841,0.867$, and 0.878 , respectively. Cronbach's alpha for the four items was 0.86 . This is similar to the 0.85 alpha reported by Cravens and Guilding (1999). The analysis indicated that the market orientation construct was reliable and unidimensional, and thus the factor scored variable was used in the statistical analyses reported on below.

\section{RESULTS}

Descriptive statistics for the CA usage rates are presented in Table 1 . The practices are presented in descending order of usage, with means ranging from 4.22, for "customer accounting”, to 2.58 for "valuation of customers or groups of customers as assets". A gulf appears between the mean usage rates of the three higher ranking practices, which all scored above the midpoint of the measurement scale, and the mean score for "lifetime CPA" and the "valuation of customers or customer groups as assets" which both yielded means well below the measure's midpoint. An analysis using the Wilcoxon two related samples test, revealed several significant differences in the relative degree to which the practices are used. ${ }^{10}$

\section{INSERT TABLE 1 HERE}

Table 2 presents descriptive statistics concerned with each of the five CA practices' perceived merit. Mean scores ranged from 5.28 to 4.19 and all were above the midpoint of the measurement scale. It should be noted that the perceived merit score for each of the five CA practices was significantly higher than their usage rate scores (for each CA

\footnotetext{
${ }^{10}$ The Wilcoxon test for difference was conducted for each CA practice. If a particular practice was found not to be used significantly more than the next highest ranking practice, it was compared to each subsequent practice appearing in Table 1 until a statistically significant difference was observed. This approach resulted in the following statistically significant observations: customer accounting used significantly more than lifetime customer profitability analysis $(p<0.001)$, customer segment profitability analysis used significantly more than lifetime customer profitability analysis $(p<0.001)$, and customer profitability analysis used significantly more than lifetime customer profitability analysis $(p<0.001)$.
} 
practice $p<0.001$; Wilcoxon related samples test). A comparison of the relative perceived merit of the CA practices revealed several significant differences. ${ }^{11}$

\section{INSERT TABLE 2 HERE}

Table 3 presents a matrix of the Pearson correlations for the five forms of CA usage and also competition intensity and market orientation. The five CA practices all exhibited statistically significantly positive inter-correlations $(p<0.001)$, with the strongest correlation between lifetime customer profitability analysis and valuation of customers or customer groups as assets ( $r=0.77$ ). The statistically significant positive correlations between competition intensity and market orientation and usage of the five CA practices suggest linear relationships. Although competition intensity and market orientation were significantly correlated $(p<0.01)$, multicollinearity does not represent a significant threat in the regression analysis undertaken, as the VIF values presented in Tables 5 and 6 are well below the generally accepted critical threshold value of 10 and the condition indices are below the generally accepted critical threshold of 30 .

\section{INSERT TABLE 3 HERE}

Table 4 presents a matrix of the Pearson correlations between the perceived merit of the five forms of CA as well as competition intensity and market orientation. The intercorrelations of the perceived merit of the five CA practices were all positive and statistically significant $(p<0.001)$. Competition intensity and market orientation were significantly positively related to the perceived merit of all five CA practices, again suggesting linear relationships.

\section{INSERT TABLE 4 HERE}

The hypotheses were tested by separately fitting each of the five CA usage rate variables and each of the five CA perceived merit variables to the following equation which includes company size as a control variable: ${ }^{12}$

$$
Y=b_{1}+b_{2} \mathrm{COMP}+b_{3} \mathrm{COMP}^{2}+b_{4} \mathrm{MARKOR}+b_{5} \mathrm{COSIZE}+e
$$

where:

$$
\begin{array}{ll}
Y & =\text { CA practice usage rate or CA practice perceived merit } \\
\text { COMP } & =\text { intensity of competition } \\
\text { COMP }^{2} & =\text { the square of intensity of competition } \\
\text { MARKOR } & =\text { market orientation }
\end{array}
$$

\footnotetext{
${ }^{11}$ Using the same approach as that described in footnote 10, it was observed that: the perceived merit of customer segment profitability analysis was significantly higher than the perceived merit of lifetime customer profitability analysis $(p<0.001)$, the perceived merit of customer accounting was significantly higher than the perceived merit of lifetime customer profitability analysis $(p<0.001)$, and the perceived merit of customer profitability analysis was significantly higher than the perceived merit of lifetime customer profitability analysis $(p<0.001)$.

12 It is an enduring finding that organisational size is positively related to greater accounting sophistication (Bruns and Waterhouse, 1975; Guilding, 1999; Merchant, 1981). Size was measured by total revenue. This was obtained from the 1996 "Shareholder" CD-Rom data base providing the survey's sample frame. As this variable exhibited a positively skewed distribution, transformation was undertaken by taking the logarithm of revenue.
} 
COSIZE $=\log$ of revenue

e

= error.

Results of the regression analysis where the five CA practice usage rates are the dependent variables are summarised in Table $5 .^{13}$ The five regression equations were statistically

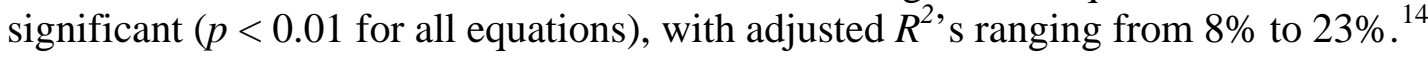

\section{INSERT TABLE 5 HERE}

From Table 5 it can be seen that no support was provided for Hypothesis 1a. The coefficient for the square of competition intensity exhibited no significant relationship with any of the CA practices. However, there was a positive and statistically significant relationship for competition intensity and customer segment profitability analysis $(p<$ 0.01). Some support was provided for Hypothesis 2a. The market orientation coefficient was positive and statistically significant in three of the five equations, i.e., where the dependent variables were customer accounting $(p<0.1)$, lifetime customer profitability analysis ( $p<0.01)$, and valuation of customers or customer groups as assets $(p<0.01)$.

Table 6 presents the regression analysis results where the perceived merit of the five CA practices are the dependent variables. Again, all regression models were significant $(p<$ 0.001 ) and the variance of the dependent variables explained by the models ranged from $17 \%$ for valuation of customers or customer groups as assets, to $32 \%$ for customer segment profitability analysis.

\section{INSERT TABLE 6 HERE}

No support was provided for Hypothesis $1 \mathrm{~b}$ as the square of competition intensity exhibited no significant relationship with the perceived merit of any of the CA practices. Competition intensity did exhibit a statistically significant positive relationship with the perceived merit of three of the five CA practices, however, i.e., customer profitability analysis $(p<0.1)$, customer segment profitability analysis $(p<0.01)$, and lifetime customer profitability analysis $(p<0.1)$. With respect to hypothesis $2 \mathrm{~b}$, market orientation exhibited a significant positive relationship to the perceived merit of CA in three of the five equations formulated. Market orientation was positively related to the perceived merit of: customer accounting ( $p<0.01)$, lifetime customer profitability analysis $(p<0.05)$, and valuation of customers or customer groups as assets $(p<0.05)$.

\footnotetext{
${ }^{13}$ Prior to performing the regression analyses, the data was screened for the existence of any influential observations through examination of residuals, calculation of leverage points, Mahalanobis distance and Cook’s distance. No influential observations were identified.

${ }^{14}$ An analysis of the findings' sensitivity to the way that competition intensity and market orientation have been measured was conducted. The measurement of each independent variable was reconstructed by substituting equal weightings for the factor analytic weightings of the five items underlying the competition intensity measure and the four items underlying the market orientation measure. These alternative measurements resulted in the following changes to the significant observations noted in Tables 5 and 6 . With respect to Table 5, the only change to the incidence of significant relationships reported concerned a positive relationship between competition intensity and customer accounting $(p<0.1)$. Four changes occurred with respect to the CA perceived merit regression results reported in Table 6. Competition intensity failed to exhibit a significant relationship with the perceived merit of customer profitability analysis and lifetime customer profitability analysis. It exhibited a positive association with perceived merit of customer accounting $(p<0.05)$, however. In addition, the square of competition intensity was significantly negatively related to customer segment profitability analysis $(p<0.1)$.
} 


\section{DISCUSSION AND CONCLUSIONS}

Three main findings emerge from this study:

1) Given the limited consideration afforded CA in the accounting literature, the results suggest a greater incidence of CA than one might have reasonably anticipated. ${ }^{15}$ Three of the five CA practices yielded means above the mid-point of the "used not at all used to a large extent" measurement scale. A potential for still further CA usage is apparent, however, as the mean scores of the perceived merit of all five CA practices appraised were above the mid-point of the measurement scale. In addition, these scores were significantly higher than their corresponding usage rates. A conspicuous aspect of the findings concerns the gap between the usage level of the three highest ranking and two lowest ranking CA practices. The two lowest ranking items ("Lifetime CPA" and "Valuation of Customers or Customer Groups as Assets") can be distinguished by their long-termist orientation. It appears that CA is another accounting technique where the long-standing criticism of accounting's short-termist tendency is again in evidence (Kaplan, 1984). The relatively low importance attached to accounting for customers as assets, which is a finding flying in the face of the relationship marketing philosophy, highlights the problem of reconciling the accounting paradigm with marketing management's conception of what constitutes an asset (Foster and Gupta, 1994; Guilding and Pike, 1990; Piercy, 1986; Wilson, 1986).

2) While no support was provided for the hypothesised inverted-U relationship between competition intensity and CA, it is noteworthy that competition intensity was found to be positively related to usage of one of the five CA practices, and perceived merit of three of the practices. It may well be that the degree of competition experienced by those respondents reporting relatively high degrees of competition intensity is insufficient to invoke the particular implications that arise in a state of perfect competition. While this study's findings pertaining to competition intensity are not strong, it appears that competition intensity offers sufficient promise to warrant further investigation. Future work would benefit from using a more objective measure of competition such as the Herfindahl-Hirschmann index ( $H$ index) that is widely used in the economics literature (Coate and McChesney, 1992; Farrell and Shapiro, 1990; Werden, 1991). Also, as Tymon et al (1998) highlight how competition intensity relates to environmental uncertainty, which is a construct that has been used in prior accounting research (Chenhall and Morris, 1986; 1993; Govindarajan, 1984; Gul and Chia, 1994), further work could benefit from investigating whether and how environmental uncertainty relates to CA.

3) Market orientation was found to be significantly positively related to the use and perceived merit of three of the five CA practices, i.e., "customer accounting", "lifetime customer profitability analysis", and "valuation of customers or customer groups as assets". There is a growing stream of research pointing towards a positive relationship between market orientation and a range of performance measures including profitability, customer retention, sales growth and new product success (Day, 1994; Narver and Slater, 1990; Slater and Narver, 1994). It might be that higher performance

\footnotetext{
${ }^{15}$ The degree of CA usage found is also considered surprising for, although Foster and Young (1997) found customer profitability to be a significant issue for managers, there is a long-standing criticism of accounting's failure to tailor information provision to the needs of marketing management (Foster and Gupta, 1994; Guilding and Pike, 1990; Ratnatunga et al., 1988). The findings reported here may signify a narrowing of the schism between marketing management's needs and accounting information provided.
} 
associated with higher market orientation plays an intervening role in the positive relationship between CA and market orientation. The importance attached to market orientation in the marketing literature and the significant role it has been found to play in this study, suggest it may be a construct worthy of consideration in subsequent accounting research concerned with dimensions of marketing management.

In addition to the usual shortcomings associated with survey research, the relative novelty of the subject under enquiry signifies a degree of subjectivity was bound to be exercised when operationalising the CA constructs. A stronger research design would result if a way could be found to measure each CA construct using multiple items. The need to present a glossary of terms to respondents highlights an additional potential for measurement error due to the onus placed on respondents to undertake additional reading and interpretation. The potential of CA usage rates scores being exaggerated as a result of respondents wanting to demonstrate familiarity with techniques they perceive as leading edge and signifying sophisticated management also needs to be borne in mind. This potential is unlikely to subvert interpretation of the ranking of the CA practice usage rates or the hypothesis testing, however, as any such exaggeration can be expected to be constant across all CA practices appraised. A final noteworthy limitation concerns the survey sample which may have contained an insufficient number of firms in markets approaching perfect competition to enable a reliable test of hypotheses 1a and 1b to be conducted.

The paucity of prior research relating to CA has hindered theory development in this study. As a result, CA case study research and also cross-sectional research exploring how industry specific factors may impinge on the benefits to be derived from CA is to be encouraged. Other contingency variables that might also be significantly related to CA include competitive strategy, organisation structure, culture and management style. While the relative novelty of this study signifies that it offers much in terms of furthering our understanding of the nature and practice of CA, its most enduring contribution might be as a catalyst for further research into the hitherto largely unchartered waters of CA. 
Table 1. Descriptive statistics for the customer accounting usage rates

\begin{tabular}{|c|c|c|c|c|c|c|c|}
\hline & \multirow[b]{2}{*}{ Mean } & \multirow[b]{2}{*}{$\mathrm{SD}$} & \multicolumn{2}{|c|}{$\begin{array}{l}\text { Theoretical } \\
\text { range }\end{array}$} & \multicolumn{2}{|c|}{$\begin{array}{l}\text { Actual } \\
\text { range }\end{array}$} & \multirow{2}{*}{$\begin{array}{l}\text { \% Incidence } \\
\text { of "N.A." }\end{array}$} \\
\hline & & & Min & Max & Min & Max & \\
\hline Customer Accounting & 4.22 & 2.14 & 1 & 7 & 1 & 7 & 15 \\
\hline $\begin{array}{l}\text { Customer Segment } \\
\text { Profitability Analysis }\end{array}$ & 4.12 & 2.12 & 1 & 7 & 1 & 7 & 17 \\
\hline $\begin{array}{l}\text { Customer Profitability } \\
\text { Analysis }\end{array}$ & 4.03 & 2.10 & 1 & 7 & 1 & 7 & 19 \\
\hline $\begin{array}{l}\text { Lifetime Customer } \\
\text { Profitability Analysis }\end{array}$ & 2.64 & 1.89 & 1 & 7 & 1 & 7 & 23 \\
\hline $\begin{array}{l}\text { Valuation of Customers or } \\
\text { Customer Groups as Assets }\end{array}$ & 2.58 & 1.96 & 1 & 7 & 1 & 7 & 22 \\
\hline
\end{tabular}

Table 2. Descriptive statistics for customer accounting perceived managerial merit

\begin{tabular}{|c|c|c|c|c|c|c|c|}
\hline & \multirow[b]{2}{*}{ Mean } & \multirow[b]{2}{*}{$\mathrm{SD}$} & \multicolumn{2}{|c|}{$\begin{array}{l}\text { Theoretical } \\
\text { range }\end{array}$} & \multicolumn{2}{|c|}{$\begin{array}{l}\text { Actual } \\
\text { range }\end{array}$} & \multirow{2}{*}{$\begin{array}{l}\text { \% Incidence } \\
\text { of “N.A.” }\end{array}$} \\
\hline & & & Min & Max & Min & Max & \\
\hline $\begin{array}{l}\text { Customer Segment } \\
\text { Profitability Analysis }\end{array}$ & 5.28 & 1.87 & 1 & 7 & 1 & 7 & 15 \\
\hline Customer Accounting & 5.21 & 1.93 & 1 & 7 & 1 & 7 & 12 \\
\hline $\begin{array}{l}\text { Customer Profitability } \\
\text { Analysis }\end{array}$ & 5.08 & 2.04 & 1 & 7 & 1 & 7 & 15 \\
\hline $\begin{array}{l}\text { Lifetime Customer } \\
\text { Profitability Analysis }\end{array}$ & 4.38 & 2.08 & 1 & 7 & 1 & 7 & 19 \\
\hline $\begin{array}{l}\text { Valuation of Customers or } \\
\text { Customer Groups as Assets }\end{array}$ & 4.19 & 2.07 & 1 & 7 & 1 & 7 & 17 \\
\hline
\end{tabular}


Table 3. Matrix of Pearson product moment correlation coefficients for the five CA usage rate variables and the two independent variables

\begin{tabular}{|c|c|c|c|c|c|}
\hline $\begin{array}{l}\text { Customer } \\
\text { Accounting }\end{array}$ & $\begin{array}{c}\text { Customer } \\
\text { Profitability } \\
\text { Analysis }\end{array}$ & $\begin{array}{c}\text { Customer } \\
\text { Segment } \\
\text { Profitability } \\
\text { Analysis }\end{array}$ & $\begin{array}{l}\text { Lifetime } \\
\text { Customer } \\
\text { Profitability } \\
\text { Analysis }\end{array}$ & $\begin{array}{c}\text { Valuation } \\
\text { of } \\
\text { Customers } \\
\text { or Customer } \\
\text { Groups as } \\
\text { Assets }\end{array}$ & $\begin{array}{c}\text { Marketing } \\
\text { Orientation }\end{array}$ \\
\hline
\end{tabular}

\section{Customer}

Profitability

$0.70^{* * *}$

Analysis

Customer Segment

Profitability

$0.60^{* * *} \quad 0.71^{* * *}$

Analysis

Lifetime Customer

Profitability

$0.54^{* * *}$

$0.57^{* * *}$

$0.60^{* * *}$

Analysis

Valuation of

Customers or

$0.40^{* * *}$

$0.45^{* * *}$

$0.54^{* * *}$

$0.77^{* * *}$

Customer Groups

as Assets

Marketing

$0.32^{* * *}$

$0.27^{* * *}$

$0.30^{* * *}$

$0.31^{* * *}$

$0.34^{* * *}$

Orientation

Competition

$0.34^{* * *}$

$0.36^{* * *}$

$0.49^{* * *}$

$0.23^{* *}$

$0.23^{* *}$

$0.44^{* * *}$

Intensity

$$
p:<0.05 ;^{* * *} p:<0.01
$$


Table 4. Matrix of Pearson product moment correlation coefficients for the five CA perceived merit variables and the two independent variables

$\begin{array}{cccccc}\text { Customer } & \text { Customer } & \text { Customer } & \text { Lifetime } & \text { Valuation } & \text { Market } \\ \text { Accounting } & \text { Profitability } & \text { Segment } & \text { Customer } & \text { of } & \text { Orientation } \\ & \text { Analysis } & \text { Profitability } & \text { Profitability } & \text { Customers } & \\ & & \text { Analysis } & \text { Analysis } & \text { or Customer } & \\ & & & & \text { Groups as } & \text { Assets }\end{array}$

\section{Customer}

Profitability

0.71

Analysis

Customer Segment

Profitability

$0.70 \quad 0.78$

Analysis

Lifetime Customer

Profitability

0.66

0.77

0.76

Analysis

Valuation of

Customers or

Customer Groups

0.63

0.66

0.69

0.77

as Assets

Market

0.47

0.34

0.31

0.37

0.34

Orientation

Competition

0.46

0.44

0.55

0.40

0.38

0.44

Intensity

All correlation coefficients are statistically significant $(p<0.001)$ 
Table 5. CA usage rates regression analysis ${ }^{\mathrm{a}}$

\begin{tabular}{|c|c|c|c|c|c|c|}
\hline & $\begin{array}{l}\text { Customer } \\
\text { Accounting }\end{array}$ & $\begin{array}{c}\text { Customer } \\
\text { Profitability } \\
\text { Analysis }\end{array}$ & $\begin{array}{l}\text { Customer } \\
\text { Segment } \\
\text { Profitability } \\
\text { Analysis }\end{array}$ & $\begin{array}{c}\text { Lifetime } \\
\text { Customer } \\
\text { Profitability } \\
\text { Analysis }\end{array}$ & $\begin{array}{c}\text { Valuation of } \\
\text { Customers or } \\
\text { Customer } \\
\text { Groups as } \\
\text { Assets }\end{array}$ & $\begin{array}{c}\text { Variable } \\
\text { Inflation } \\
\text { Factor }\end{array}$ \\
\hline Constant & $\begin{array}{l}2.54^{* * *} \\
(3.04)\end{array}$ & $\begin{array}{l}2.68^{* * *} \\
(3.24)\end{array}$ & $\begin{array}{l}3.12^{* * *} \\
(3.96)\end{array}$ & $\begin{array}{l}2.02^{* * *} \\
(2.88)\end{array}$ & $\begin{array}{l}2.44^{* * *} \\
(3.42)\end{array}$ & \\
\hline $\begin{array}{l}\text { Competition } \\
\text { intensity }\end{array}$ & $\begin{array}{c}0.06 \\
(0.47)\end{array}$ & $\begin{array}{c}0.15 \\
(1.12)\end{array}$ & $\begin{array}{l}0.33^{* * *} \\
(2.66)\end{array}$ & $\begin{array}{c}0.11 \\
(0.82)\end{array}$ & $\begin{array}{c}0.19 \\
(1.40)\end{array}$ & 2.41 \\
\hline $\begin{array}{l}\text { (Competition } \\
\text { intensity) }\end{array}$ & $\begin{array}{c}-0.16 \\
(-1.31)\end{array}$ & $\begin{array}{c}-0.14 \\
(-1.14)\end{array}$ & $\begin{array}{c}-0.11 \\
(-0.99)\end{array}$ & $\begin{array}{c}0.03 \\
(0.21)\end{array}$ & $\begin{array}{c}0.11 \\
(0.92)\end{array}$ & 2.09 \\
\hline $\begin{array}{l}\text { Market } \\
\text { orientation }\end{array}$ & $\begin{array}{l}0.17^{*} \\
(1.75)\end{array}$ & $\begin{array}{c}0.11 \\
(1.14)\end{array}$ & $\begin{array}{c}0.08 \\
(0.91)\end{array}$ & $\begin{array}{l}0.26^{* * *} \\
(2.63)\end{array}$ & $\begin{array}{l}0.32^{* * *} \\
(3.30)\end{array}$ & 1.31 \\
\hline $\begin{array}{l}\text { Company } \\
\text { size }\end{array}$ & $\begin{array}{l}0.18^{*} \\
(1.92)\end{array}$ & $\begin{array}{c}0.14 \\
(1.39)\end{array}$ & $\begin{array}{c}0.09 \\
(0.99)\end{array}$ & $\begin{array}{c}0.04 \\
(0.43)\end{array}$ & $\begin{array}{c}-0.04 \\
(-0.42)\end{array}$ & 1.33 \\
\hline Adjusted $R^{2}$ & 0.16 & 0.14 & 0.23 & 0.08 & 0.10 & \\
\hline$F$ & 6.68 & 5.95 & 10.43 & 3.61 & 4.52 & \\
\hline$p$ & 0.00 & 0.00 & 0.00 & 0.01 & 0.00 & \\
\hline
\end{tabular}

$n=124$

a Each cell presents the standardised regression coefficient followed by the $t$-value in parenthesis. All $t$-tests are two-tailed tests of significance.

${ }^{*} p:<0.1 ; \quad{ }^{* * *} p:<0.01$.

Condition indices: 1.00; 1.18; 1.99; 3.45; 9.68. 
Table 6. CA perceived merit regression analysis ${ }^{\mathbf{a}}$

\begin{tabular}{|c|c|c|c|c|c|c|}
\hline & $\begin{array}{c}\text { Customer } \\
\text { Accounting }\end{array}$ & $\begin{array}{c}\text { Customer } \\
\text { Profitability } \\
\text { Analysis }\end{array}$ & $\begin{array}{l}\text { Customer } \\
\text { Segment } \\
\text { Profitability } \\
\text { Analysis }\end{array}$ & $\begin{array}{l}\text { Lifetime } \\
\text { Customer } \\
\text { Profitability } \\
\text { Analysis }\end{array}$ & $\begin{array}{l}\text { Valuation of } \\
\text { Customers or } \\
\text { Customer } \\
\text { Groups as } \\
\text { Assets }\end{array}$ & $\begin{array}{c}\text { Variable } \\
\text { Inflation } \\
\text { Factor }\end{array}$ \\
\hline Constant & $\begin{array}{l}3.85^{* * *} \\
(5.18)\end{array}$ & $\begin{array}{l}3.07^{* * *} \\
(3.74)\end{array}$ & $\begin{array}{l}3.54^{* * *} \\
(4.78)\end{array}$ & $\begin{array}{l}2.28^{* * *} \\
(2.81)\end{array}$ & $\begin{array}{l}2.47^{* * *} \\
(3.06)\end{array}$ & \\
\hline $\begin{array}{l}\text { Competition } \\
\text { intensity }\end{array}$ & $\begin{array}{c}0.14 \\
(1.20)\end{array}$ & $\begin{array}{l}0.22^{*} \\
(1.76)\end{array}$ & $\begin{array}{l}0.33^{* * *} \\
(2.83)\end{array}$ & $\begin{array}{l}0.23^{*} \\
(1.87)\end{array}$ & $\begin{array}{c}0.20 \\
(1.58)\end{array}$ & 2.41 \\
\hline $\begin{array}{l}\text { (Competition } \\
\text { intensity) })^{2}\end{array}$ & $\begin{array}{c}-0.16 \\
(-1.47)\end{array}$ & $\begin{array}{c}-0.10 \\
(-0.85)\end{array}$ & $\begin{array}{c}-0.17 \\
(-1.56)\end{array}$ & $\begin{array}{c}0.03 \\
(0.24)\end{array}$ & $\begin{array}{c}-0.02 \\
(-0.19)\end{array}$ & 2.09 \\
\hline $\begin{array}{l}\text { Market } \\
\text { orientation }\end{array}$ & $\begin{array}{l}0.29^{* * *} \\
(3.35)\end{array}$ & $\begin{array}{c}0.14 \\
(1.55)\end{array}$ & $\begin{array}{c}0.04 \\
(0.48)\end{array}$ & $\begin{array}{l}0.22^{* *} \\
(2.42)\end{array}$ & $\begin{array}{l}0.19^{* *} \\
(2.02)\end{array}$ & 1.31 \\
\hline $\begin{array}{l}\text { Company } \\
\text { size }\end{array}$ & $\begin{array}{l}0.15^{*} \\
(1.67)\end{array}$ & $\begin{array}{l}0.20^{* *} \\
(2.13)\end{array}$ & $\begin{array}{l}0.18^{* *} \\
(2.10)\end{array}$ & $\begin{array}{l}0.18^{* *} \\
(1.99)\end{array}$ & $\begin{array}{l}0.16^{*} \\
(1.71)\end{array}$ & 1.33 \\
\hline Adjusted $R^{2}$ & 0.30 & 0.23 & 0.32 & 0.21 & 0.17 & \\
\hline$F$ & 14.07 & 10.12 & 15.77 & 9.01 & 7.42 & \\
\hline$p$ & 0.00 & 0.00 & 0.00 & 0.00 & 0.00 & \\
\hline
\end{tabular}

$n=124$

${ }^{a}$ Each cell presents the standardised regression coefficient followed by the $t$-value in parenthesis. All $t$-tests are two-tailed tests of significance.

${ }^{*} p:<0.10 ;{ }^{* *} p:<0.05 ;{ }^{* * *} p:<0.01$.

Condition indices: $1.00 ; 1.18 ; 1.99 ; 3.45 ; 9.68$. 


\section{APPENDIX A}

\section{GLOSSARY OF CUSTOMER ACCOUNTING PRACTICES}

\section{Customer Accounting:}

Includes all accounting practices directed towards appraising profit, sales, or present value of earnings relating to a customer or group of customers.

\section{Customer Profitability Analysis:}

This involves calculating profit earned from a specific customer. The profit calculation is based on costs and sales that can be traced to a particular customer. This technique is sometimes referred to as "Customer Account Profitability".

\section{Lifetime Customer Profitability Analysis:}

This involves extending the time horizon for customer profitability analysis to include future years. The practice focuses on all anticipated future revenue streams and costs involved in servicing a particular customer.

\section{Customer Segment Profitability Analysis:}

This is the practice of performing a customer profitability analysis (as defined above), on a market segment or customer group basis.

Valuation of Customers or Customer Groups as Assets:

Refers to the calculation of the value of customers to the company. For example, this could be undertaken by computing the present value of all future profit streams attributable to a particular customer or group of customers. 


\section{BIBLIOGRAPHY}

Albrecht, K. (1988). At America’s Service, Dow-Jones-Irwin: Homewood, IL.

Bellis-Jones, R. (1989). Customer Profitability Analysis. Management Accounting, 67, 2, 26-28.

Berry, D. (1977). Profit Contribution: Accounting and Marketing Interface. Industrial Marketing Management, 6, 125-128.

Bruns, W.J., Jr., and Waterhouse, J.H. (1975). Budgetary Control and Organization Structure, Journal of Accounting Research, Autumn, 177-203.

Chenhall, R. H. and Morris, D. (1986). The impact of structure, environment, and interdependence on the perceived usefulness of management accounting systems, The Accounting Review, 61, 16-35.

Chenhall, R. H. and Morris, D. (1993). The role of post completion audits, managerial learning, environmental uncertainty and performance, Behavioral Research in Accounting, $5,170-186$.

Christopher, M., Payne, A. and Ballantyne, D. (1991). Relationship Marketing, Butterworth-Heinemann, Oxford.

Coate, M. B., and McChesney, F. S. (1992). Empirical evidence on FTC enforcement of the merger guidelines, Economic Inquiry, 30, 277-293.

Cooper, R. and Kaplan, R.S. (1991). The Design of Management Systems, Prentice-Hall Inc., New Jersey.

Cravens, D.W. (1995). Introduction to Special Issue, Journal of the Academy of Marketing Science, 23, 4, 235.

Cravens, D.W., Greenley, G., Piercy, N.F. and Slater, S. (1997). Integrating Contemporary Strategic Management Perspectives, Long Range Planning, 30, 4, 493-506.

Cravens, K. and Guilding, C., (1999) Examining Brand Valuation from a Management Accounting Perspective, Advances in Management Accounting, 8, 113-137.

Cronbach, L. J. (1951). Coefficient Alpha and the Internal Structure of Tests, Psychometrika, 297-334.

Day, G. S. (1994). The Capabilities of Market-Driven Organizations, Journal of Marketing, 58 (October), 37-52.

Dudick, T.S. (1987). Why SG\&A Doesn’t Always Work, Harvard Business Review, JanFeb, 1987, 22-24.

Dwyer, F.R., Schurr, P.H. and Oh, S. (1987). Developing Buyer-Seller Relationships, Journal of Marketing, 51, 11-27. 
Evans, J.R. and Berman, B. (1994). Marketing, $6^{\text {th }}$ ed., New York: Macmillan Publishing.

Farrell, J. and Shapiro, C. (1990). Horizontal mergers: an equilibrium analysis, American Economic Review, 80, 107-126.

Feigenbaum, A.V. (1983). Total Quality Control, New York: McGraw-Hill.

Foster, G. and Gupta, M. (1994). Marketing, Cost Management and Management Accounting, Journal of Management Accounting Research, 6, 43-77.

Foster, G., Gupta, M. and Sjoblom L. (1996). Customer Profitability Analysis: Challenges and New Directions, Cost Management, Spring, 5-17.

Govindarajan, V. (1984). Appropriateness of Accounting Data in Performance Evaluation: An Empirical Examination of Environmental Uncertainty as an Intervening Variable, Accounting, Organizations and Society, 9, 2, 125-136.

Guilding, C. (1999). Competitor-focused accounting: an exploratory note, Accounting Organizations and Society, 24, 583-595.

Guilding, C., Kennedy, D. and McManus L. (2001). Extending the boundaries of customer accounting: applications in the hotel industry, Journal of Hospitality and Tourism Research, 25, 2, 173-194.

Guilding, C. and Pike, R. (1990). Intangible Marketing Assets: A Managerial Accounting Perspective, Accounting and Business Research, 21, 18, 41-49.

Gul, F. and Chia, Y. M. (1994). The effects of management accounting systems, perceived environmental uncertainty and decentralization on managerial performance: A test of three-way interaction, Accounting, Organizations and Society, 19, 413-426.

Hair, J. F. Jr., Anderson, R. E., Tatham, R. L. and Black, W. C. (1995). Multivariate Data Analysis, 4th ed., Englewood Cliffs, New Jersey: Prentice Hall.

Hansen, D.R. and Mowen, M.M. (1997). Management Accounting, 4th edn., Cincinnati, Ohio: South Western Publishing.

Hartfeil, G. (1996). Bank One Measures Profitability of Customers, Not Just Products, Journal of Retail Banking Services, 18, 2, 24-31.

Hudson, P. (1994). Big Banks Focus on Customers Too, Bank Marketing, 26, 11, 60.

Juras, P.E., and Dierks, P.A. (1994). Blue Ridge Manufacturing, Management Accounting, Dec., 57-59.

Kaplan, R.S. (1984). Yesterday's Accounting Undermines Production, Harvard Business Review, July-Aug., 95-101. 
Kaplan, R.S. and Norton, D.P. (1992). The Balanced Scorecard - Measures that Drive Performance, Harvard Business Review, 70, 1, 71-79.

Kaplan, R. S. and Norton, D.P. (1996). The Balanced Scorecard - Translating Strategy into Action, Boston, Ma: Harvard Business School Press.

Khandwalla, P. (1972) The Effects of Different Types of Competition on the Use of Management Control, Journal of Accounting Research, Autumn, 275-285.

Kohli, A. and Jaworski B. (1990), Market Orientation: The Construct, Research Propositions, and Managerial Implications, Journal of Marketing, 54, 1-18

Kotler, P. (1984), Marketing Management: Analysis, Planning and Control. Englewood Cliffs, NJ: Prentice-Hall.

Kotler, P. and Andreasen A. R. (1987), Strategic Marketing for Nonprofit Organizations, Englewood Cliffs, NJ: Prentice-Hall.

Levitt, T. (1960), Marketing Myopia, Harvard Business Review, 38, 4, 45-56.

Levitt, T. (1983). After the Sale is Over, Harvard Business Review, 61, Sept/Oct, 87-93.

Lynch, R.L. and Cross, K. F. (1991). Measure Up! Cambridge, Ma: Blackwell Publishers.

Merchant, K.A. (1981). The Design of the Corporate Budgeting System: Influences on Managerial Behavioural and Performance, The Accounting Review, 56, 4, 813-829.

Narver J.C. and Slater S.F. (1990). The Effect of a Market Orientation on Business Profitability, Journal of Marketing, 3, 20-35.

O’Guin M. and Rebishke S. (1993). Customer-Driven Costs Using Activity-Based Costing, in Handbook of Cost Management, Brinker B., (ed.) New York: Warren Gorham Lamont.

Quain, W.J. (1992). Analyzing Sales-Mix Profitability, Cornell H. R. A. Quarterly, April, 57-62.

Ratnatunga, R., Pike, R. and Hooley, G.J. (1988). The Application of Management Accounting Techniques to Marketing, Accounting and Business Research, 18, 72, 363370.

Reicheld, F.F. (1993). Loyalty Based Management, Harvard Business Review, 71, 2, 6473.

Reicheld, F.F. and Sasser, W.E. (1990). Zero Defections: Quality Comes to Services, Harvard Business Review, Sept.-Oct., 105-111.

Rolfe, A.J. (1992). Profitability reporting techniques bridge information gap, The Journal of Business Strategy, 32-37. 
Shapiro, B.P., Rangan, V.K., Moriarty, R.T. and Ross, E.B. (1987). Manage Customers For Profits (Not Just Sales), Harvard Business Review, Sept.-Oct., 101-108.

Simons, R., (1990). The Role of Management Control Systems in Creating Competitive Advantage: New Perspectives, Accounting, Organizations and Society, 15, 1/2, 127-143.

Slater, S. F. and Narver, J. C., (1994). Market Orientation, Customer Value, and Superior Performance, Business Horizons, March-April, 22-28.

Smith, M. and Dikolli, S. (1995). Customer Profitability Analysis: An Activity-based Approach, Managerial Auditing Journal, 10, 7, 3-7.

Sonnenberg, F.K. (1994). The Age Of Intangibles, Management Review, 83, 1, 49-53.

Tabachnick, B. G. and Fidell, L. S. (1996). Using Multivariate Statistics, 3rd ed., New York: Harper Collins.

Tomkins, C. and Groves R. (1983). The Everyday Accountant and Researching His Reality, Accounting, Organizations and Society, 8, 4, 361-374.

Turnbull, P.W. and Wilson, D.T. (1989). Developing and Protecting Profitable Customer Relationships, Industrial Marketing Management, 18, 233-238.

Tymon, W. G., Stout, D. E. and Shaw, K. N. (1998). Critical Analysis and Recommendations Regarding the Role of Perceived Environmental Uncertainty in Behavioral Accounting Research, Behavioral Research in Accounting, 10, 23-46.

Ward, K. (1992). Accounting for Marketing Strategies in Management Accounting Handbook, edited by C. Drury, Butterworth-Heineman Ltd, Oxford, England.

Wayland, R.E. and Cole, P.M. (1994). Turn Customer Service into Customer Profitability, Management Review, 83, 7, 22-24.

Webster, F. E. (1988). Rediscovering the Marketing Concept, Business Horizons, 31, 2939.

Werden, G. J. (1991). Horizontal mergers: comment, American Economic Review, 81, 1002-1006.

Zink, K.J. (1995). Total Quality Management as a Holistic Management Concept, New York: Springer. 